\title{
Argon plazma koagülasyon: Durdurulamayan özofagus varis kanamalarında alternatif endoskopik kurtarma tedavisi olabilir mi?
}

Can argon plasma coagulation be endoscopic recovery treatment in uncontrolled esophageal varices bleeding?

\section{Hüseyin Sancar BOZKURT}

Özel Tarsus Medikal Park Hastanesi, Gastroenteroloji Bölümü, Mersin

Özofagus varis kanaması portal hipertansiyonun 6 haftalık mortalite oranının yaklaşık \%20 olduğu yaşamı tehdit edici bir komplikasyonudur. Günümüz verisi vazoaktif ilaçlarla endoskopik varis ligasyonu, antibiyotik kombinasyonunun en iyi tedavi edici yöntem olduğunu desteklemektedir. Doku yapıştırıcılar, endolooplar, endoskopik klipsleme ve argon plazma koagülasyon kontrol edilemeyen özofagus varis kanamasında kullanılmaktadır.

Anahtar kelimeler: Özofagus varis kanaması, portal hipertansiyon, argon plazma koagülasyon

Akut özofagus varis kanaması (AÖVK), karaciğer sirozu ve daha az sıklıkla splenik ven trombozunun ciddi ve ölümcül bir komplikasyonudur. Farmakolojik ve endoskopik tedavilere rağmen mortalite \%20'lere ulaşabilmektedir(1). Balon tamponad, endoskopik skleroterapi, transjuguler intrahepatik portosistemik şant, kurtarma tedavisi alternatiflerinden olmakla birlikte bazı sınırlamaları vardır (2). Argon plasma koagülasyon (APK) ile uygulanan ablatif işlem endoskopik kurtarma tedavisi olabilir (3). 77 yaşında 2 yl önce özofagus varis kanaması ve bant ligasyonu öyküsü olan Hepatit C'ye bağlı Child-Pugh B siroz hastası erkek hasta ve 47 yaşında 1 yll önce özofagus varis kanaması ve bant ligasyonu öyküsü olan alkole bağlı Child-Pugh C ile takipte erkek hasta AÖVK ile kliniğimize yatırıldı. Hastalara vazoaktif, antibiyotik tedavi başlanarak hemodinamik stabilizasyon sonrası yapılan endoskopide aktif pulsatil kanama gösteren belirgin tortüyoze olmayan varis izlendi. Endoskopik bant ligasyon işlemi varisin tortüyoze olmaması nedeniyle başarılı olmadı. Hastalara standard ve düşük çıkıs gücünde (30 watt) APK işlemi uygulandı. Her iki hastada aktif kanamanın durduğu izlendi (Resim 1-2) ve kontrol endoskopilerinde kanama yerinin proksimalindeki tortüyoze varislere bant ligasyonu uygulandıktan sonra hastalar takibe alındı. APK işlemi özofagusta daha çok Barrett özofagus gibi displazi ve neoplazi lezyonlarında uygulanan endoskopik ablatif bir işlemdir (4). Peptik ülser, dieulafoy
Esophageal variceal bleeding is a life-threatening complication of portal hypertension with a six-week mortality rate of approximately $20 \%$. The available data suggest that vasoactive drugs, combined with endoscopic therapy and antibiotics, are the best treatment strategy with endoscopic variceal ligation being the endoscopic procedure of choice. Tissue adhesives, endoloops, endoscopic clipping and argon plasma coagulation, have been used in the management of uncontrolled esophageal varices bleeding.

Key words: Esophageal variceal bleeding, portal hypertension, argon plasma coagulation

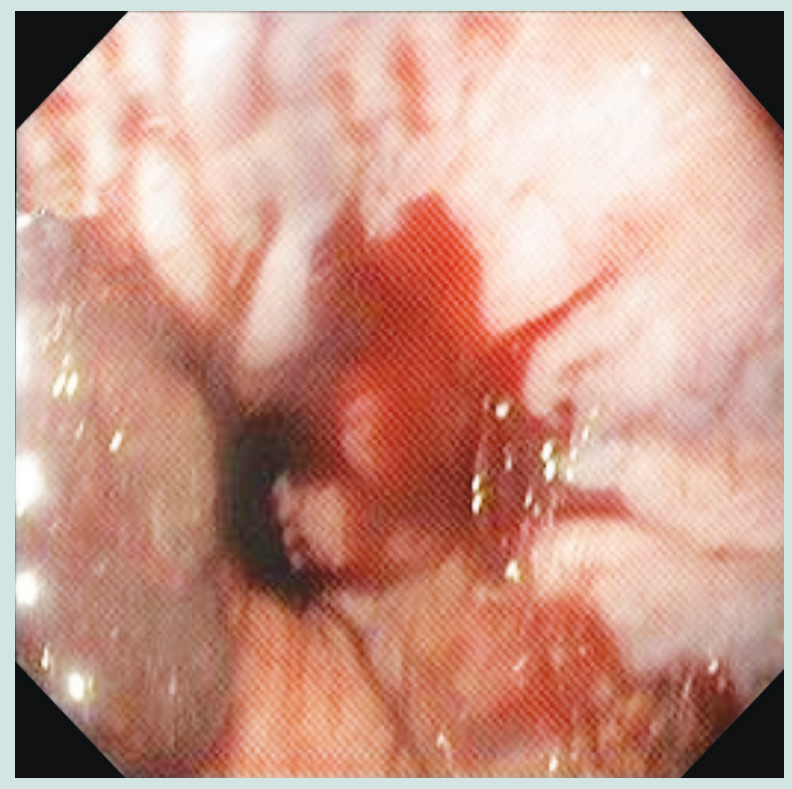

Resim 1. Aktif özofagus varis kanaması.

gibi kanamalı lezyonlarda endoskopik koagülasyon yöntemi olarak da kullanılmasına rağmen özofagustaki aktif kanama gösteren lezyonlardaki kullanımına ilişkin veriler çok kısıtlıdır (5). APK işlemi AÖVK olan hastalarda endoskopik veya kurtarma tedavisi olarak düşünülebilir. 


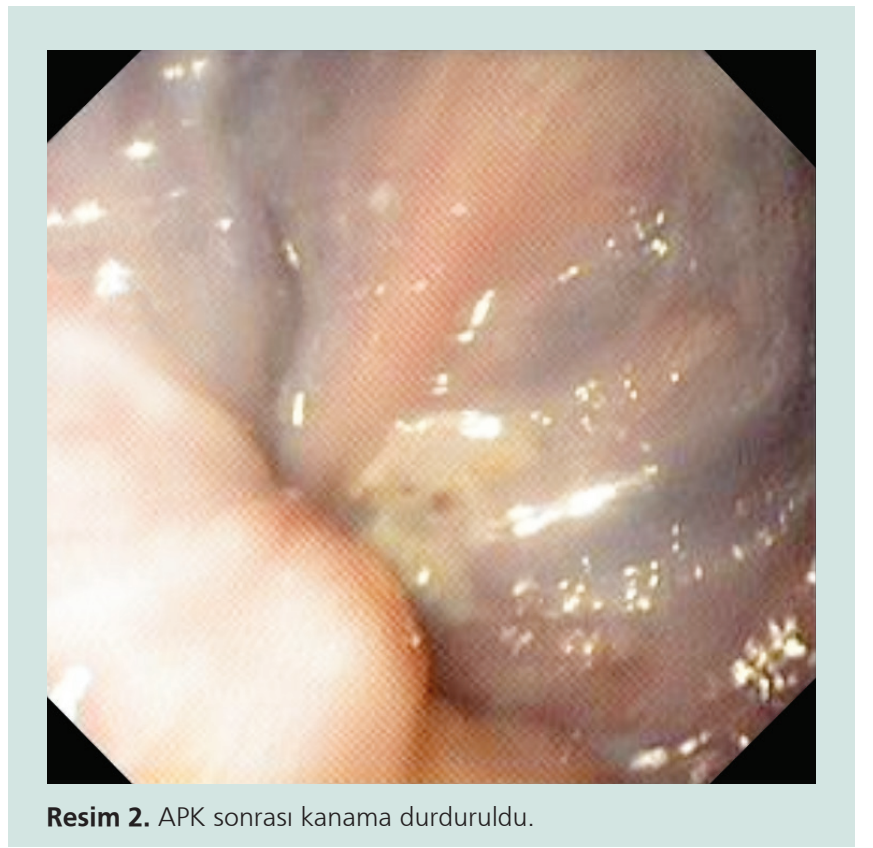

\section{KAYNAKLAR}

1. Calès P, Pascal JP. Natural history of esophageal varices in cirrhosis (from origin to rupture) Gastroenterol Clin Biol 1988;12:245-54

2. Villanueva C, Colomo A, Aracil C et al. Current endoscopic therapy of variceal bleeding. Best Pract Res Clin Gastroenterol 2008;22:261-78

3. Harras F, Sheta el S, Shehata M, et al. Endoscopic band ligation plus argon plasma coagulation versus scleroligation for eradication of esophageal varices. J Gastroenterol Hepatol 2010;25:1058-65

4. van Vilsteren FG, Pouw RE, Seewald S, et al. Stepwise radical endoscopic resection versus radiofrequency ablation for Barrett's oesophagus with high-grade dysplasia or early cancer: a multicentre randomised trial. Gut 2011;60:765-73.

5. Olmos JA, Marcolongo M, Pogorelsky V, et al. Argon plasma coagulation for prevention of recurrent bleeding from GI angiodysplasias. Gastrointest Endosc 2004;60:881-6. 